\title{
Pelatihan Pengolahan Tepung Telur Untuk Meningkatkan Pengetahuan Kelompok PKK dan Kelompok Wanita Tani Desa Jatinom Kanigoro Blitar
}

\author{
Lestariningsih $^{(1)}$, Rosidi Azis ${ }^{(2)}$ dan Binti Khopsoh ${ }^{(3)}$ \\ 1,2,3 Dosen Prodi Peternakan Fakultas Ilmu Eksakta \\ Universitas Nahdlatul Ulama Blitar \\ ${ }^{1}$ lestariningsih@unublitar.ac.id, ${ }^{2}$ rosidiazis@ unublitar.ac.id, \\ 3bintikhopsoh@unublitar.ac.id
}

Tersedia Online di

http://www.jurnal.unublitar.ac.id/

index.php/briliant

\begin{tabular}{l}
\hline Sejarah Artikel \\
\hline Diterima pada 29 November 2018 \\
Disetuji pada 9 Februari 2019 \\
Dipublikasikan pada 20 Februari \\
2019 Hal. 22-26 \\
\hline
\end{tabular}

Kata Kunci:

Telur, tepung telur, jatinom dan pelatihan

DOI:

http://dx.doi.org/10.28926/briliant .v3i3.258

\begin{abstract}
Abstrak: Blitar merupakan salah satu produsen telur terbesar di Indonesia. Setiap harinya kurang lebih 450 ton telur keluar dari Blitar. Desa Jatinom merupakan salah satu Desa di Blitar yang cukup berpotensi dalam produksi telur. Namun demikian, telur tersebut masih dijual dalam bentuk segar dan hanya dijadikan bahan konsumsi lauk pauk seperti biasanya. Selain itu, telur merupakan salah satu produk ternak yang mudah sekali terkontaminasi mikroorganisme sehingga mudah mengalami kerusakan. Oleh karena itu perlu bimbingan kepada Kelompok PKK dan Kelompok Wanita Tani sebagai organisasi sosial Desa Jatinom untuk mengolah telur menjadi tepung telur. Tepung telur merupakan salah satu produk yang cukup mudah pengolahaannya dan dapat meningkatkan daya simpan telur. Metode yang digunakan dalam pengabdian ini adalah survei, wawancara dan pelatihan. Hasil yang didapatkan bahwa terdapat peningkatan $45 \%$ pengolahan telur menjadi tepung telur.
\end{abstract}

\section{PENDAHULUAN}

Jatinom merupakan salah satu Desa yang terletak di Kecamatan Kanigoro Kabupaten Blitar. Desa ini memiliki luas wilayah $22.050 \mathrm{Km}^{2}$. Wilayah tersebut terdiri dari pemukiman penduduk, tanah tegalan, perkebunan, persawahan, dan lahan kering. Pada Desa ini banyak masyarakat yang berprofesi sebagai buruh tani ternak. Disamping itu, Blitar merupakan salah satu daerah penyuplai telur di Indonesia. Berdasarkan data dari Dinas Peternakan dan Perikanan Kab. Blitar diketahui bahwa kurang lebih 450 ton telur perhari keluar dari Blitar. Telur tersebut dalam bentuk segar. Telur segar dijual keluar kota. Hal ini disebabkan karena pemenuhan telur segar diluar kota yang tinggi dan belum mampunya masyarakat setempat mengolah telur tersebut. Disisi lain ada permasalah ketika telur tidak segera diolah maka akan mudah rusak. Hal ini disebabkan telur mempunyai sifat mudah terkontaminasi sehingga daya simpannya relatif rendah. Jika produksi terus meningkat maka akan menimbulkan masalah kerusakan telur yang semakin tinggi.

Salah satu alternatif sebagai solusi pengolahan telur yang mudah adalah dengan mengolah telur segar menjadi tepung telur. Tepung telur merupakan olahan tepung yang berasal dari telur segar. Prinsip dalam pengolahan tepung telur tersebut adalah dengan mengurangi kadar air didalam telur. Kandungan air telur berkisar antara $60-70(\%)$. Penguapan kadar air dalam proses pembuatan 
tepung telur ini berkisar antara $60-70(\%)$. Penguapan kadar air tersebut dapat dilakukan dengan proses pengeringan. Pengeringan dapat dilakukan dengan menggunakan spray dryer, oven, microvawe dan dengan menggunakan bantuan sinar matahari. Daya simpan tepung telur dapat lebih dari 1 bulan. Cara - cara tersebut belum banyak diterapkan oleh masyarakat khususnya didaerah pedesaan.

Pengolahan tepung telur ini sangat terjangkau jika dilakukan pengolahan oleh ibu - ibu khususnya. Ibu - ibu dalam pedesaan pada umumnya bergabung kepada kelompok PKK dan kelompok wanita Tani. Aslichati (2011) menyatakan bahwa organisasi PKK merupakan salah satu organisasi sosial desa yang bergerak dalam bidang pemberdayaan perempuan desa untuk meningkatkan kualitas kehidupan masyarakat perempuan tersebut. Sumber pembiayaan organisasi PKK adalah swadaya gotong royong dan partisipasi masyarakat. Bantuan pemerintah dan bantuan dari sumber lainnya sifatnya sebagai pendorong dan perangsang untuk tumbuh dan berkembangnya partisipasi masyarakat, sehingga pada awalnya keberadaan PKK merupakan salah satu tindak lanjut dari kebijakan pemerintah pusat (top-down policy) yang diarahkan untuk lebih meningkatkan partisipasi masyarakat dalam mewujudkan keluarga yang sejahtera. Selain itu, Shalfiah (2013) menambahkan bahwa fungsi dan peran PKK sebagai fasilitator dan penyuluh dalam mendukung atau menunjang program pemerintah desa khususnya. Partisipasi masyarakat khususnya perempuan dalam mengikuti PKK merupakan salah satu terobosan untuk mengembangkan diri dan meminimalisir permasalahan keluarga.

Mengingat perannya pentingnya organisasi sosial desa khususnya PKK dan Wanita Tani maka perlu pelatihan terhadap organisasi tersebut untuk selanjutnya bisa ditindak lanjuti kepada keluarga. Salmah (2012) menyatakan bahwa program pelatihan bertujuan untuk mengembangkan kemampuan seseorang. Tujuan pengembangan program tersebut adalah untuk meningkatkan kinerja dari seseorang baik secara individu ataupun lembaga. Oleh karena itu, perlu dilaksankan pelatihan pengolahan tepung telur untuk meningkatkan pengetahuan kelompok PKK dan Wanita Tani Desa Jatinom Kecamatan Kanigoro Kabupaten Blitar. Tujuan pelaksanaan program ini adalah untuk meningkatkan produktivitas ibu - ibu PKK dan Kelompok Wanita Tani (KWT) Desa Jatinom Kecamatan Kanigoro Kabupaten Blitar. Pelaksanaan program ini diharapkan dapat bermanfaat bagi masyarakat Desa Jatinom khususnya dalam mengolah telur segar menjadi tepung telur untuk meningkatkan produktivitas ibu - ibu PKK dan KWT Desa Jatinom Kecamatan Kanigoro Kabupaten Blitar. Selain itu, melalui program ini diharapkan dapat dijadikan bahan referensi dalam aplikasi pengolahan telur untuk meningkatkan produktivitas masyarakat.

\section{METODE}

Kegiatan ini dilaksanakan di Desa Jatinom Kecamatan Kanigoro Kabuoaten Blitar pada bulan September hingga November 2018. Objek dalam kegiatan ini adalah Kelompok PKK dan Kelompok Wanita Tani (KWT) Desa Jatinom Kecamatan Kanigoro Kabupaten Blitar sebanyak 50 orang. Metode yang digunakan dalam pengabdian ini adalah survei, wawancara dan pelatihan. Sedangkan analisis data dilaksanakan dengan pendekatan deskriptif kualitatif. 


\section{HASIL}

Hasil penelitian ini tercantum dalam Gambar 1.

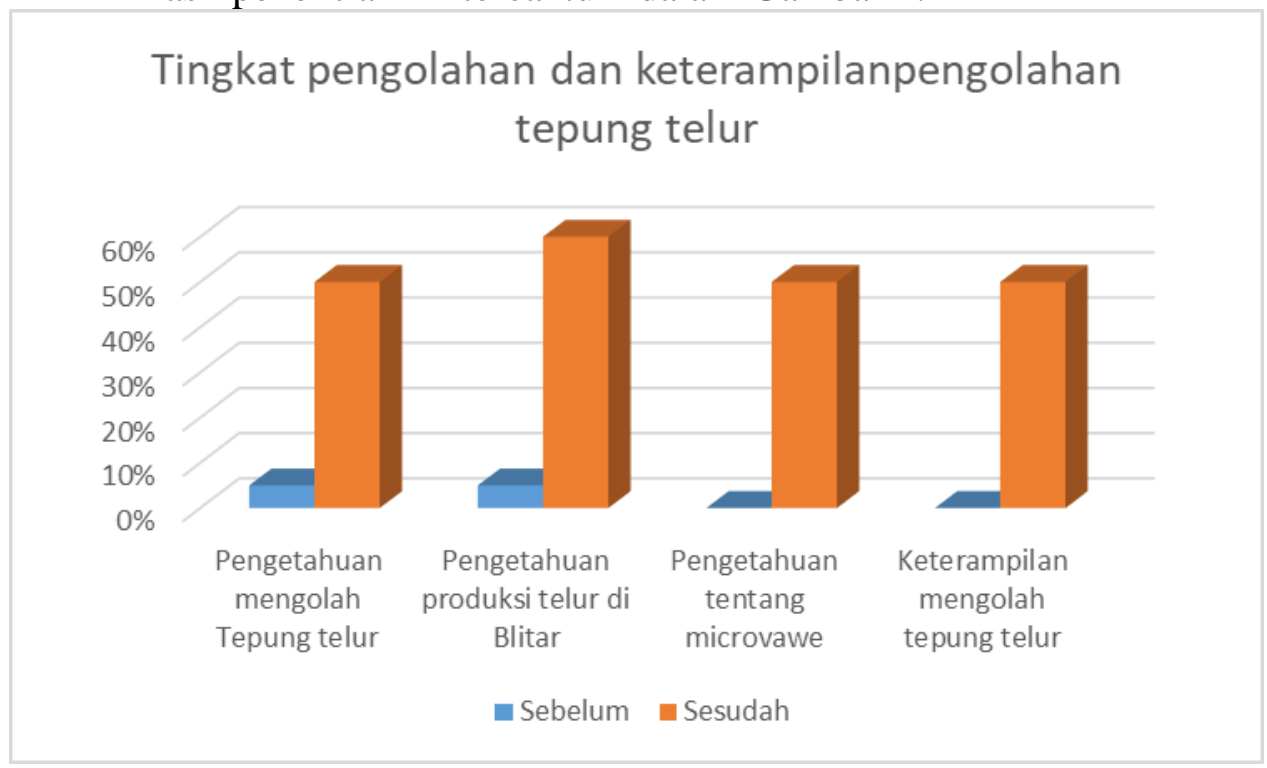

Gambar 1. Peningkatan pengetahuan kelompok PKK dan Wanita Tani sebelum dan sesudah dilaksanakan pelatihan

\section{PEMBAHASAN}

Program pelatihan ini (Gambar 2.) dilaksanakan pada bulan September hingga November 2018 dengan Mitra Kelompok PKK dan Kelompok Wanita Tani Desa Jatinom Kecamatan Kanigoro Kabupaten Blitar.

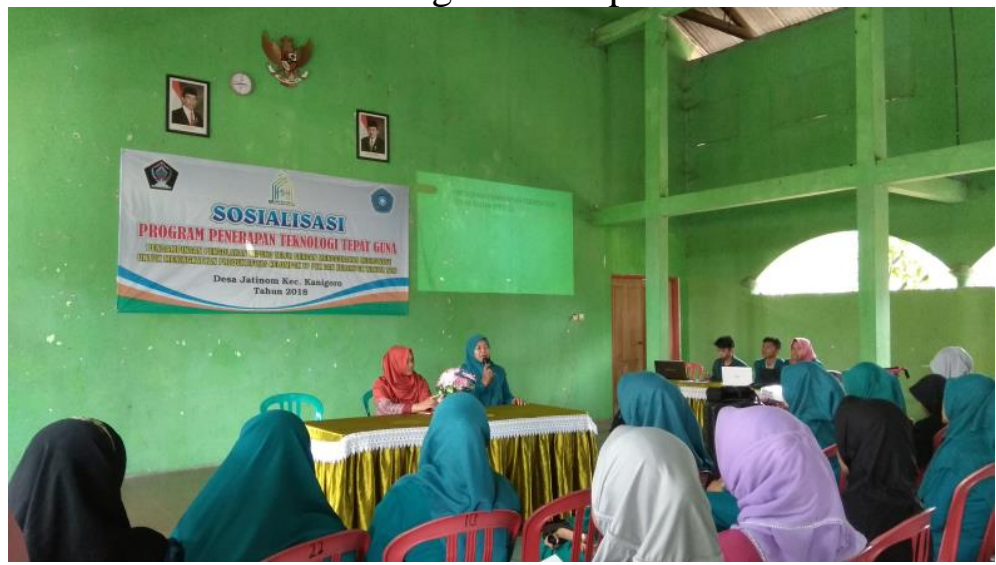

Gambar 2. Pelatihan pembuatan tepung telur

Kegiatan pelatihan ini diikuti oleh 50 peserta dari kelompok PKK dan Wanita Tani Desa Jatinom. Sebelum dimulai kegiatan pelatihan maka diadakan survey melalui angket. Berdasarkan angket tersebut diketahui bahwa 95\% masyarakat tidak mengetahui bahwa telur bisa diolah menjadi tepung telur. Setelah dilakukan pelatihan terdapat peningkatan $45 \%$ kelompok mengetahui bahwa telur dapat diolah menjadi tepung telur dan dapat mengetahui cara pengolahannya (Gambar 1). Peningkatan pengetahuan tersebut diharapkan akan meningkatkan perekomian masyarakat. Aswiyati (2016) menyatakan bahwa ada sebuah usaha untuk meningkatkan peranan dan sumbangan wanita dalam pembangunan, termasuk untuk menunjang perekonomian keluarga. Selain itu, wanita dalam pembangunan dapat pula menunjang perekonomian keluarga. 
Potensi wanita yang cukup besar jumlahnya itu mempunyai arti dan mengambil bagian secara aktif baik dalam pembangunan dan meningkatkan perekonomian keluarga.

Pelatihan terhadap organisasi social desa perlu dilakukan karena organisasi desa adalah icon dalam mendukung pembangunan desa dengan menggerakkan masyarakat desa. Menurut Turere (2013), sebuah organisasi membutuhkan sumber daya manusia yang mempunyai semangat kerja yang tinggi untuk mengembangkan organisasinya tersebut. Hal ini bisa dilakukan melalui sebuah pelatihan dan pengembangan. Selain itu, Pranadji (2006) menambahkan bahwa pemberdayaan masyarakat pedesaan tidak akan berhasil jika tidak dilandaskan pada penguatan modal sosial setempat. Elemen modal sosial yang dinilai penting adalah tata nilai, kompetensi SDM, amnahemen sosial, keorganisasian masyarakat, struktur sosial, kepemimpinan dan penyelenggaraan pemerintah yang baik. Pemberdayaan masyarakat tersebut bertujuan untuk kemandirian kelompok masyarakat. Syahra (2003) menyatakan bahwa sekelompok masyarakat harus mampu mandiri dalam mengembangkan potensi masyarakat setempat. Hal ini dapat dilakukan setelah adanya sebuah pendampingan dari pihak internal maupuan eksternal. Selain itu, pemberdayaan masyarakat ini juga dapat mengentaskan masyarakat dari kemiskinan. Sidik (2015) menyatakan bahwa kemiskinan merupakan salah satu masalah dalam masyarakat Desa. Pemerintah desa berperan signifikan dalam penglolaan proses social didalam masyarakat. Salah satu tugas pemerintah desa dalah memberikan pelayanan kehidupan sosial untuk meningkatkan kesejahteraan masyarakat.

\section{KESIMPULAN}

Pelatihan pengolahan telur segar menjadi tepung telur dapat meningkatkan pengetahuan kelompok PKK dan Wanita Tani sebanyak $45 \%$.

\section{SARAN}

Kegiatan pelatihan ini dilanjutkan dengan kegiatan pendampingan untuk meningkatkan pengetahuan dan keterampilan Kelompok PKK dan Kelompok Wanita Tani Desa Jatinom.

\section{DAFTAR RUJUKAN}

Aslichati, L. 2011. Organisasi pemberdayaan dan kesejahteraan keluarga sebagai sarana pemberdayaan perempuan. Jurnal Organisasi dan Managemen 7 (1) : $1-7$.

Aswiyati, I. 2016. Peran wanita dalam menunjang perekonomian rumah tangga keluarga petani tradisional untuk penanggulangan kemiskinan di Desa Kuwil Kecamatan Kalawat. Jurnal Holistik 17 (1).

Pranadji, T. 2006. Penguatan modal sosial untuk permberdayaan masyarakat pedesaan dalam pengelolaan agroekosistem lahan kering. Jurnal Agro Ekonomi 24 (2) : 178 - 206.

Salmah, N.N.A. 2012. Pengaruh program pelatihan dan pengembangan karyawan terhadap kompetensi karyawan pada PT. Muba Electric Power sekayu. Jurnal Ekonomi dan Informasi Akuntasi (Jenius) 2 (3). 
Shalfiah, R. 2013. Peran pemberdayaan dan kesejahteraan keluarga (PKK) dalam mendukung program program pemerintah Kota Bontang. Jurnal Ilmu Pemerintahan 1 (3) : 975 - 984.

Sidik, F. 2015. Menggali potensi lokal mewujudkan kemandirian Desa. Jurnal Kebijakan dan administrasi Publik 19 (2).

Syahra, R. 2003. Modal sosial : Konsep dan aplikasi. Jurnal Masyarakat dan Budaya 5 (1).

Turere, V.N. 2013. Pengaruh pendidikan dan pelatihan terhadap peningkatan kinerja karyawan pada Balai Pelatihan Teknis Pertanian Kalasey. Jurnal EMBA 1 (3) : 10 - 19. 